\author{
Artur Iwiński \\ Wyższa Szkoła Umiejętności Społecznych im. prof. Michała Iwaszkiewicza \\ studiaai@interia.pl
}

\title{
Instytucja ponaglenia w postępowaniu administracyjnym
}

\section{The concept of a request for expediting in the administrative proceedings}

\section{STRESZCZENIE}

Celem artykułu jest przedstawienie wprowadzonego do Kodeksu postępowania administracyjnego nowego środka zaskarżenia jakim jest ponaglenie. Wcześniej, gdy organ nie załatwił sprawy w terminie strona mogła wnieść zażalenie. Zażaleniu należy przeciwstawić ponaglenie. W pierwszej części pracy omówiono wybrane zasady jak i terminy obowiązujące w k.p.a. Kolejne części dotyczą m.in. definicji legalnych bezczynności i przewlekłości prowadzonego postępowania administracyjnego. Informuje o tym kto może wnieść ponaglenie. Jakie są sposoby jego rozpoznawania. Dowiemy się również jakie są konsekwencje opieszałości organów. Widmo możliwości wniesienia ponaglenia przez stronę bądź uczestnika postępowania, dyscyplinuje i mobilizuje organy administracji publicznej do działania.

Słowa kluczowe: ponaglenie; środek zaskarżenia; opieszałość organów; bezczynność; przewlekłość

\section{WSTĘP}

Dawniej zażalenie, dziś już ponaglenie w Kodeksie postępowania administracyjnego z 14 czerwca 1960 roku¹. W związku z nowelizacją k.p.a. z dnia 1 czerwca 2017 roku, warto się pochylić nad wprowadzoną instytucją ponaglenia.

Ponaglenie jest środkiem, który mobilizuje prace organów administracji publicznej. Dyscyplinuje organy do respektowania ogólnie przyjętych zasad, likwiduje opieszałość organów, które poprzez nie załatwianie spraw w ustawowych terminach

1 Ustawa z dnia 14 czerwca 1960 r. - Kodeks Postępowania administracyjnego Dz. U. 1960 Nr 30 poz. 168, dalej: k.p.a. 
muszą się liczyć z możliwością wniesienia skargi na bezczynność bądź przewlekłość postępowania i jej uwzględnienia przez sąd administracyjny. W związku z powyższym wydaje się zasadne, aby najpierw ustalić zasady, następnie określić terminy, co w dalszej kolejności pozwoli na zrozumienie instytucji ponaglenia.

Celem badań jest udzielenie odpowiedzi na następujące pytania badacze: Czy instytucja ponaglenia w rzeczywistości doprowadzi do szybszego działania organów administracji publicznej? Czy ustawodawca postąpił prawidłowo wprowadzając do ustawy k.p.a. definicje legalne bezczynności i przewlekłości postępowania administracyjnego?

W artykule przedstawiono $\mathrm{w}$ oddzielnych częściach zagadnienia dotyczące:

- zasad związanych z instytucją ponaglenia;

- wyjaśnienia pojęć: bez zbędnej zwłoki oraz niezwłocznie;

- definicji legalnych bezczynności i przewlekłości;

- objaśnienia wcześniejszego zażalenia, a dzisiejszego ponaglenia;

- podmiotów mogących wnieść ponaglenie;

- sposobów rozpoznawania ponaglenia;

- konsekwencji opieszałości organów.

Badania zostały przeprowadzone metodą monograficzną z wykorzystaniem podstawowych metod badawczych takich jak: analizy literatury, badanie prawa oraz analizy orzecznictwa sądowego. Wnioski z przeprowadzonych badań zostały zawarte w zakończeniu.

\section{ZASADY ZWIĄZANE Z INSTYTUCJĄ PONAGLENIA}

Postępowanie administracyjne opiera się na wielu zasadach, które w znacznej części są wprost wymienione w k.p.a, natomiast niektóre jednak są dorobkiem doktryny jak i orzecznictwa. Wszystkie zasady ogólne mają charakter norm prawnych, nie zaś wskazówek czy zaleceń ${ }^{2}$. W celu omówienia problematyki ponaglenia, należy w pierwszej kolejności przytoczyć kilka wybranych zasad, które są związanie z tym środkiem zaskarżenia.

Do grupy pierwotnej zasad idei stosowania prawa zgodnie z art. 7 k.p.a., można zaliczyć zasadę prawdy materialnej, która połączona jest z zasadą praworządności wywodzącej się z art. 6 Konstytucji Rzeczypospolitej Polskiej z dnia 2 kwietnia $1996 \mathrm{roku}^{3}$. Zasadzie tej przyznaje się rolę naczelną w ukształtowaniu czynności postępowania, zakresu środków dowodowych i określeniu obowiązków

2 Z. R. Kmiecik, Postępowanie administracyjne, postępowanie egzekucyjne w administracji i postępowanie sądowoadministracyjne, Warszawa 2017, s. 48.

${ }_{3}$ Konstytucja Rzeczypospolitej Polskiej z dnia 2 kwietnia 1997 r. (Dz.U. nr 78, poz. 483 ze zm.). 
dowodowych organów i stron związanych z wyjaśnieniem stanu faktycznego i prawnego sprawy4.

Natomiast do grupy pochodnej idei stosowania prawa możemy zaliczyć zasadę pogłębiania zaufania, zgodnie z którą to na organach administracji publicznej spoczywa obowiązek prowadzenia postępowania w sposób budzący zaufanie jego uczestników do władzy publicznej. Realizacja tej zasady odnosi się w równej mierze do podejmowania przewidzianych prawem czynności postępowania, jak też do ich treści oraz stosowania prawa materialnego, a także do stosunku pracownika do stron i uczestników postępowania w toku prowadzenia tych czynności, a więc do wymagań kultury administrowania ${ }^{5}$. Określenie katalogu zachowań służących realizacji tej zasady nie jest możliwe, tak jak nie jest możliwe sprecyzowanie listy zasad współżycia społecznego ${ }^{6}$.

Z grupy zasad kultury administrowania możemy wyróżnić zasadę udzielania informacji, która oznacza, że organy czuwają nad tym, aby strony i inne osoby uczestniczące $\mathrm{w}$ postępowaniu administracyjnym nie poniosły szkody z powodu nieznajomości prawa $\mathrm{i} w$ tym celu organy udzielają im niezbędnych wyjaśnień. Zasada ta może służyć za przykład realistycznego podejścia ustawodawcy do unormowania stosunków między organem prowadzącym postępowanie a uczestnikami tego postępowania ${ }^{7}$. Obowiązek informacyjny wynikający z art. 9 k.p.a. musi być wykonywany przez organ z urzędu, bez osobnych wniosków stron lub uczestników postępowania, i rozciąga się on na wszystkie stadia i czynności postępowania, aż do ich zakończenia w danej instancji administracyjnej ${ }^{8}$.

Ze względu na decydującą rolę organu administracji w postępowaniu administracyjnym potrzebne było nałożenie na organy administracji obowiązku jak najszybszego rozstrzygania spraw administracyjnych' ${ }^{9}$. Obowiązek ten wywodzi się z rodzaju zasad techniczno-procesowych, gdzie możemy wyróżnić zasadę szybkości i prostoty postępowania, zgodnie z którą organy administracji publicznej powinny działać w sprawie wnikliwie i szybko, posługując się możliwie najprostszymi środkami prowadzącymi do jej załatwienia zgodnie z art. 12 k.p.a. Szybkość postępowania administracyjnego leży zarówno w interesie obywatela, jak i w interesie społecznym; winna ona cechować dobrze pracującą administrację, która powinna

4 B. Adamiak, J. Borkowski, Postępowanie administracyjne i sądowoadministracyjne, Warszawa 2018, s. 46-47.

5 Ibidem, s. 50.

6 Z. Kmieciak, Postępowanie administracyjne w świetle standardów europejskich, Warszawa 1997, s. 111

W. Dawidowicz, Postępowanie administracyjne Zarys wykładu, Warszawa 1983, s. 91.

8 B. Adamiak, J. Borkowski, op. cit., s. 56.

9 M. Szubiakowski, M. Wierzbowski, A. Wiktorowska, Postępowanie administracyjne-ogólne, podatkowe i egzekucyjne, Warszawa 1996, s. 43. 
działać sprężyście i racjonalnie organizować swą pracę ${ }^{10}$. Treść tej zasady musi być rozpatrywana w łączności z szeregiem unormowań Kodeksu postępowania administracyjnego wiążących organy administracyjne terminami dokonywania czynności procesowych oraz załatwiania spraw, ustanawiających dla stron terminy wykorzystywania uprawnień procesowych, środków procesowych dyscyplinujących uczestników postępowania ${ }^{11}$.

\section{BEZ ZBĘDNEJ ZWŁOKI ORAZ NIEZWŁOCZNIE}

Celem terminów w każdym postępowaniu jest zapewnienie szybkiego i sprawnego załatwienia sprawy administracyjnej ${ }^{12}$. Ustawodawca reguluje w k.p.a. terminy w których to organy administracji publicznej powinny załatwiać sprawy. Terminy w pewnym sensie dyscyplinują czynności organu administracji publicznej. Prawodawca wykorzystał już do tego celu najpierw dewolucję kompetencji, czyli przeniesienia sprawy do wyższej instancji działającej za opieszałą niższą instancję, potem zasadę sygnalizowania organowi nadzoru przypadków niezałatwienia sprawy w terminie ${ }^{13}$.

Artykuł $35 \S 1$ k.p.a. związany jest z art. $12 \S 1$ k.p.a. czyli działaniem organu bez zbędnej zwłoki. W art. $35 \S 2$ k.p.a. ustawodawca używa terminu niezwłocznie. Termin bez zbędnej zwłoki należy rozumieć jako działanie organu w sposób natychmiastowy, organ ma działać od razu. Natomiast niezwłocznie organ administracji publicznej powinien działać w kilku przypadkach o których mowa w k.p.a. Sformułowanie kodeksowe należy rozumieć jako generalną wskazówkę dotyczącą załatwienia wszystkich spraw w postępowaniu administracyjnym w taki sposób, by nie tylko dochować terminów zakreślonych w Kodeksie, ale by w miarę możliwości załatwić sprawy w terminach krótszych niż wyznaczone ${ }^{14}$. Wojewódzki Sąd Administracyjny w Gdańsku stwierdził, że dążenie organu prowadzącego postępowanie do jak najszybszego załatwienia sprawy nie powinno jednak prowadzić do naruszenia zasady prawdy obiektywnej ${ }^{15}$.

Należy wskazać, że organ powinien działać niezwłocznie, gdy do koncentracji materiału dowodowego dochodzi z chwilą wszczęcia postępowania administra-

10 E. Ochendowski, Postępowanie administracyjne ogólne, egzekucyjne i sądowoadministracyjne, Toruń 2008, s. 97.

11 B. Adamiak, J. Borkowski, op. cit., s. 58.

12 M. Szubiakowski, M. Wierzbowski, A. Wiktorowska, op. cit., s. 91.

13 B. Adamiak, J. Borkowski, op. cit., s. 241.

14 K. Celińska-Grzegorczyk, R. Hauser, W. Sawczyn, A. Skoczylas, Postępowanie administracyjne, sądowoadministracyjne i egzekucyjne, Warszawa 2009, s. 55-56.

15 Wyrok Wojewódzkiego Sądu Administracyjnego w Gdańsku z dnia 18 stycznia 2017 r., sygn. II SAB/Gd 149/16. 
cyjnego, gdy strona bądź też uczestnik postępowania na prawach strony dołącza z podaniem właściwie wszystkie potrzebne dowody do wydanie decyzji administracyjnej. Kolejna sytuacja ma miejsce, gdy decyzja administracyjna może być wydana jedynie o fakty powszechnie znane często nazywane faktami notorycznymi. Ponadto, gdy decyzja administracyjna może zostać wydana o fakty znane organowi administracyjnemu z urzędu. Gdy decyzja administracyjna może zostać wydana o fakty którymi rozporządza organ.

Organ administracji publicznej prowadzący sprawy, które jednak wymagają przeprowadzenia wnikliwego postępowania wyjaśniającego powinny zostać załatwione $\mathrm{w}$ terminie jednego miesiąca. Jednak, gdy sprawa administracyjna jest szczególnie skomplikowana nie później niż w ciągu dwóch miesięcy od dnia wszczęcia postępowania administracyjnego, zaś w postępowaniu odwoławczym w ciągu miesiąca od dnia otrzymania odwołania. Kodeks nie określa, jakie kategorie spraw są „,szczególnie skomplikowane”, ani nie ustala jaki organ ma prawo określić, że sprawa jest szczególnie skomplikowana ${ }^{16}$. Należałoby przyjąć, że zakwalifikowanie spraw o znaczeniu szczególnie skomplikowanym, jest w gestii organu administracji publicznej pierwszej instancji.

Mamy również postępowania uproszczone w których sprawy powinny być załatwione niezwłocznie nie później jednak niż w terminie miesiąca od dnia wszczęcia postępowania. Należy również pamiętać, że przepisy szczególne mogą określić inne terminy.

Terminy dokonania czynności procesowych w pewnym zakresie dynamizują postępowanie, ale przede wszystkim odgrywają rolę gwarancyjną dla stron i uczestników postępowania ${ }^{17}$.

Do biegu terminów wskazanych w art. 35 § 3 k.p.a. nie wlicza się m.in. terminów przewidzianych w przepisach prawa dla dokonania określonych czynności, np. terminu na usunięcie przez stronę braków podania zgodnie z art. 64 § 2 k.p.a., okresów zawieszenia postępowania zgodnie z art. $35 \S 5$ k.p.a. oraz z art. 103 k.p.a. Nie wlicza się okresów opóźnień powstałych z winy strony w sytuacji np. niedostarczenia przez stronę określonych dokumentów w wyznaczonym przez organ administracji publicznej termie. Nie wlicza się również okresów opóźnień powstałych z przyczyn niezależnych od organu. Do takich przyczyn można zaliczyć, np. niestawienie się prawidłowo wezwanego świadka na rozprawę, gdzie w konsekwencji organ odroczy rozprawę zgodnie z art. $94 \S 2$ k.p.a.

Należy pamiętać, że terminy do załatwienia spraw określone w art. $35 \S 3$ k.p.a. mają charakter maksymalny. Upływ terminu nie pozbawia organu możliwości orzekania w sprawie, jak i też nie powoduje wadliwości wydanej w takim postępowaniu

\footnotetext{
16 E. Ochendowski, op. cit., s. 97.

17 B. Adamiak, J. Borkowski, op. cit., s. 246.
} 
decyzji. Te maksymalne terminy mogą być w odniesieniu do określonych spraw zastąpione terminami określonymi w przepisach ustaw odrębnych ${ }^{18}$.

Zgodnie z wymienioną wcześniej zasadą udzielania informacji organ administracji publicznej jest obowiązany zawiadomić strony o każdym przypadku niezałatwienia sprawy w terminie określonym $\mathrm{w}$ art. 35 k.p.a. lub w przepisach szczególnych, podając przyczyny zwłoki i wskazując nowy termin załatwienia sprawy. Obowiązek sygnalizacji stronom o niezałatwieniu sprawy w terminie ustawowym ciąży na organie administracyjnym również wówczas, gdy zwłoka w załatwieniu sprawy nastąpiła z przyczyn niezależnych od organu ${ }^{19}$.

Naczelny Sąd Administracyjny w wyroku stwierdził, że nowy termin załatwienia sprawy może być uznany za skutecznie wyznaczony w trybie art. $36 \S 1$ k.p.a., jeżeli zostanie wskazany przez organ właściwy do załatwienia sprawy zgodnie z art. 57 k.p.a. (tj. w dniach, tygodniach lub miesiącach) i z zachowaniem ogólnej zasady szybkości postępowania określonej w art. $12^{20}$.

\section{DEFINICJE LEGALNE BEZCZYNNOŚCI I PRZEWLEKŁOŚCI}

Bezczynność organu administracji publicznej oznacza w odniesieniu do art. $37 \S$ 1 pkt 1 k.p.a, nie załatwienia sprawy w terminie określonym $w$ art. 35 lub przepisach szczególnych jak i w terminie wskazanym zgodnie $\mathrm{z}$ art. $36 \S 1$.

Zgodnie z art. $37 \S 1$ pkt 2 k.p.a przewlekłość zachodzi, gdy postępowanie jest prowadzone dłużej niż jest to niezbędne do załatwienia sprawy. Przewlekłość będzie zatem miała miejsce, gdy np. bezzasadnie organ zawiesił postępowanie, podejmował zbędne dla ustalenia stanu faktycznego czynności dowodowe ${ }^{21}$. Naczelny Sąd Administracyjne stwierdził w wyroku, iż poprzez pojęcie przewlekłego prowadzenia postępowania należy rozumieć sytuację prowadzenia postępowania w sposób nieefektywny poprzez wykonywanie czynności w dużym odstępie czasu. Ponadto mogą to być również działania pozorne powodujące, że formalnie organ nie jest bezczynny lub mnożenie czynności dowodowych ponad potrzebę wynikającą $z$ istoty spraw ${ }^{22}$. Wprowadzone definicje legalne tych terminów pozostawiają dużo mniejsze możliwości subiektywnej oceny wykładni przepisów prawa, stwarzającą korzystniejszą sytuację dla organu administracji publicznej.

18 B. Adamiak, J. Borkowski, Postępowanie administracyjne i sądowoadministracyjne, Warszawa 2013, s. 200.

19 E. Ochendowski, op. cit., s. 99.

20 Wyrok Naczelnego Sądu Administracyjnego (NSA) z dnia 21 czerwca 1996 r., sygn. I SAB 28/96.

21 B. Adamiak, J. Borkowski, op. cit., s. 245.

22 Wyrok Naczelnego Sądu Administracyjnego (NSA) z dnia 10 lutego 2015 r., sygn. II OSK $2104 / 14$. 


\section{WCZEŚNIEJ ZAŻALENIE, DZIŚ PONAGLENIE}

Przed nowelizacją k.p.a. z czerwca 2017 roku, stronie postępowania administracyjnego przysługiwał środek zaskarżenia w postaci zażalenia. Na niezałatwienie sprawy w terminie stronie służy zażalenie do organu administracji publicznej wyższego stopnia, uznając zażalenie za uzasadnione, wyznacza dodatkowy termin załatwienia sprawy oraz zarządza wyjaśnienie przyczyn i ustalenie osób winnych niezałatwienia sprawy $\mathrm{w}$ terminie, a w razie potrzeby także podjęcie środków zapobiegających naruszeniu terminów załatwienia sprawy w przyszłości ${ }^{23}$. To zażalenie było wówczas jedynym środkiem zaskarżenia, które przysługiwało na milczenie organu, a nie na postanowienie. Dlatego możliwość wniesienia tego zażalenia istnieje tak długo, dopóki organ prowadzący postępowanie nie ogłosi bądź nie doręczy stronie decyzji administracyjnej ${ }^{24}$. Ten środek zaskarżenia, jakim jest zażalenie, właściwe jest do zaskarżania działań organu, a nie do jego zaniechań. To zażalenie stanowiło wyłam od ogólnie przyjętej regulacji zażalenia o której mowa w art. 141-144 k.p.a.

Dziś jest to już ponaglenie, czyli nowa ścieżka zwalczająca opieszałość organów. Ustawą z 7.04.2017 r. o zmianie ustawy - Kodeks postępowania administracyjnego oraz niektórych innych ustaw ${ }^{25}$, wprowadzono w miejsce zażalenia do organu wyższego stopnia, a w razie braku organu wyższego stopnia wezwania do usunięcia naruszenia praw, ponaglenie ${ }^{26}$. Instytucja ta została więc wyróżniona od innych środków zaskarżenia i zachowana tym samym została czystość konstrukcji prawnej. Ponaglenie nie dotyczy fragmentu postępowania administracyjnego jak zażalenie, a jego całości.

\section{PODMIOTY MOGĄCE WNIEŚĆ PONAGLENIE}

Zgodnie z art. 37 k.p.a. stronie postępowania administracyjnego służy prawo do wniesienia ponaglenia $\mathrm{w}$ dwóch przypadkach, a mianowicie gdy mamy do czynienia z bezczynnością organu administracyjnego oraz z przewlekłością postępowania administracyjnego. Prawo wniesienia ponaglenia mają również uczestnicy postępowania na prawach strony. Organizacja społeczna dopuszczona do udziału w postępowaniu „uczestniczy w postępowaniu na prawach strony” (art. $31 \S 3$

${ }^{23}$ K. Chorąży, W. Taras, A. Wróbel, Postępowanie administracyjne, egzekucyjne i sądowoadministracyjne, Zakamycze 2005, s. 80.

24 E. Ochendowski, op. cit., s. 100.

25 Ustawa z dnia 7 kwietnia 2017 r. o zmianie ustawy - Kodeks postępowania administracyjnego oraz niektórych innych ustaw Dz.U. 2017 poz. 935

26 B. Adamiak, J. Borkowski, op. cit., s. 243. 
k.p.a. $)^{27}$. Do innych uczestników postępowania na prawach strony należy prokurator $^{28}$. W postępowaniu administracyjny również Rzecznik Praw Obywatelskich może występować jako uczestnik postępowania na prawach strony. Jego zakres procesowych uprawnień odsyła do praw procesowych prokuratora. Nie oznacza to jednak, że nie ma odrębności w pozycji prawnej Rzecznika w postępowaniu administracyjnym ${ }^{29}$.

\section{SPOSOBY ROZPOZNAWANIA}

Ustawodawca rozróżnia sposób samego procedowania nad ponagleniem w zależności od tego do którego organu administracji publicznej wpłynie ponaglenie, a co za tym idzie wskazuje na dwie możliwości.

Model klasyczny to sytuacja w której ponaglenie, podobnie z resztą jak zażalenie, wpływa do organu wyższego stopnia, ale za pośrednictwem organu, który prowadził daną sprawę. Zgodnie z k.p.a. organ ma obowiązek przekazania ponaglenia wraz z niezbędnymi odpisami akt. Owe rozwiązanie jest w swej istocie niebywale ważne, ponieważ w takiej sytuacji organ nie wyzbywa się akt sprawy i może dalej procedować $\mathrm{w}$ danej sprawie, a odpisy mogą być również sporządzone $\mathrm{w}$ wersji dokumentu elektronicznego - co również przyspiesza postępowanie. Przekazanie ponaglenia do organu wyższego stopnia ma nastąpić bez zbędnej zwłoki, a więc tak szybko jak to jest możliwe, nie później jednak niż w terminie siedmiu dni od dnia otrzymania ponaglenia.

Zauważyć należy, że to nie jedyny obowiązek organu w przypadku przekazania ponaglenia. Kolejnym jest to, że organ ma obowiązek ustosunkowania się do wniesionego ponaglenia i wyjaśnienia dlaczego pozostawał w bezczynności bądź przewlekłości. Wskazać należy, że nie jest żadnym uzasadnieniem choroba pracownika, nadmiar pracy pracownika czy urlop pracownika. Wojewódzki Sąd Administracyjny w Gliwicach w wyroku uznał, że brak obecności w pracy pracownika zajmującego się określonym referatem w urzędzie nie może pozbawiać urzędu dynamiki załatwiania spraw ${ }^{30}$.

W przedmiocie złożonego ponaglenia w klasycznym modelu organ nadzoru wydaje postanowienie w którym stwierdza czy organ rozpatrujący sprawę dopuścił się bezczynności bądź przewlekłości i wskazuje czy miało ono miejsce z rażącym naruszeniem prawa, co z kolei związane jest z ustawą o odpowiedzialności ma-

27 E. Ochendowski, op. cit., s. 88.

28 M. Szubiakowski, M. Wierzbowski, A. Wiktorowska, op. cit., s. 68.

29 B. Adamiak, J. Borkowski, op. cit., s. 160.

30 Wyrok Wojewódzkiego Sądu Administracyjnego w Gliwicach z dnia 25 września 2014 r., sygn. IV SAB/G1 92/14. 
jątkowej funkcjonariuszy publicznych za rażące naruszenie prawa. Ponadto organ nadzoru, gdy stwierdzi bezczynność bądź przewlekłość jest zobligowany do zobowiązania organu prowadzącego postępowanie do jego zakończenia w wyznaczonym terminie przez organ. Dodatkowo zarządza wyjaśnienia przyczyn i ustalenia osób winnych bezczynności bądź przewlekłości.

$\mathrm{Z}$ modelem mniej klasycznym złożenia ponaglenia, spotkamy się w sytuacji, gdy organem, który prowadził postępowanie jest Samorządowe Kolegium Odwoławcze, czy Minister, gdyż organy te nie mają organu wyższego stopnia, wówczas sami rozpoznają złożone ponaglenie. W przypadku gdy ponaglenie nie ma konstrukcji dewolucyjnej, a jest to rozpatrywane przez organ, który dopuścił się bezczynności lub przewlekłości, nie jest wydawane postanowienie, organ zaś po ustaniu bezczynności lub przewlekłości niezwłocznie załatwia sprawę oraz zarządza wyjaśnienie przyczyn i ustalenia osób winnych bezczynności lub przewlekłości, a w razie potrzeby także środków zapobiegających bezczynności lub przewlekłości w przyszłości ${ }^{31}$.

\section{KONSEKWENCJE OPIESZAŁOŚCI ORGANÓW}

Pracownik organu administracji publicznej jeśli z nieuzasadnionych przyczyn nie rozstrzygnął sprawy w terminie lub gdy prowadził sprawę dłużej niż było to niezbędne do załatwienia sprawy podlega odpowiedzialności porządkowej lub dyscyplinarnej albo innej odpowiedzialności o której mowa w przepisach prawa. Ta inna odpowiedzialność może być wynikiem, np. roszczeń regresowych organu administracji publicznej, jeżeli poniesie on odpowiedzialność za szkodę wyrządzoną niedotrzymaniem terminów załatwienia spraw ${ }^{32}$. Kolejną konsekwencją opieszałości organu może być skarga do sądu administracyjnego. Zgodnie z orzeczeniem Wojewódzkiego Sądu Administracyjnego w Poznaniu, aby móc wnieść skargę, musi upłynąć termin rozpatrzenia ponaglenia ${ }^{33}$. Jest to nowe i odmienne stanowisko od wcześniej utrwalonej praktyki. Wcześniej przyjmowało się, że wystarczy wniesienie zażalenia na bezczynność, bez konieczności oczekiwania na jego rozstrzygnięcie. Zauważyć należy, że skargi nie kieruje się bezpośrednio do sądu, ale do organu, którego zaniechanie jest przedmiotem skargi, czyli skargę wnosi się za pośrednictwem organu. Wnosi się ją w terminie trzydziestu dni od dnia doręczenia skarżącemu rozstrzygnięcia w sprawie. Ponadto sąd z urzędu

31 B. Adamiak, J. Borkowski, op. cit., s. 244.

32 Ustawa z dnia 20 stycznia 2011 r. o odpowiedzialności majątkowej funkcjonariuszy publicznych za rażące naruszenie prawa (Dz. U. z 2016r. poz. 1169 ze zm.).

33 Postanowienie Wojewódzkiego Sądu Administracyjnego w Poznaniu z dnia 7 grudnia 2017 r., sygn. IV SAB/Po 70/17. 
albo na wniosek strony może także orzec o wymierzeniu organowi administracji publicznej grzywny lub przyznać od organu na rzecz skarżącego sumę pieniężną, której wysokość określona jest w k.p.a. Wojewódzki Sąd Administracyjny w Łodzi orzekł, że grzywna nie ma na celu wyłącznie dyscyplinowania organów administracji, ale ma w szerszym zakresie przeciwdziałać ich opieszałości w prowadzeniu spraw oraz służyć usuwaniu negatywnych skutków wynikających z bezczynności postępowania ${ }^{34}$. Ten nowy rodzaj skarg otwiera szeroko prawo do sądu jednostce dotkniętej niesprawnym działaniem organów administracji publicznej ${ }^{35}$. Zgodnie $\mathrm{z}$ art. 149 § 1 ustawy prawo o postępowaniu przed sądami administracyjnymi z dnia 30 sierpnia 2002 roku sąd uwzględniając skargę na bezczynność lub przewlekłe prowadzenie postępowania zobowiązuje organ do wydania w określonym terminie aktu, interpretacji albo do dokonania czynności. Jednocześnie zobowiązuje organ do stwierdzenia albo uznania uprawnienia lub obowiązku wynikających z przepisów prawa, a także stwierdza, że organ dopuścił się bezczynności lub przewlekłego prowadzenia postępowania. Z kolei zgodnie z art. 149 § 1a sąd stwierdza jednocześnie, czy bezczynność organu lub przewlekłe prowadzenie postępowania przez organ miały miejsce z rażącym naruszeniem prawa ${ }^{36}$. Natomiast sąd nie może nakazywać organowi sposobu rozstrzygnięcia ani też bezpośrednio orzekać o prawach lub obowiązkach skarżącego ${ }^{37}$.

\section{PODSUMOWANIE}

Należy stwierdzić, iż nowelizacja Kodeksu postępowania administracyjnego w 2017 roku i wprowadzona w związku z nią instytucja ponaglenia jest niebywale istotna. Nastąpiło wyodrębnienie środka zaskarżenia na bezczynność lub przewlekłość i przeciwstawienie go zażaleniu dzięki czemu została zachowana czystość konstrukcji prawnej. Ponaglenie zostało w sposób jasny sprecyzowane i z założenia ma zwalczać opieszałość organów. Ponaglenie daje jednostce poczucie możliwości respektowania prawa.

Zatem na pierwsze pytanie badawcze należy odpowiedzieć w sposób twierdzący. Widmo sankcji grożących organowi, a co za tym idzie funkcjonariuszom publicznym dyscyplinuje organ i mobilizuje pracowników organu do organizacji

34 Wyrok Wojewódzkiego Sądu Administracyjnego w Łodzi z dnia 8 grudnia 2015 r., sygn. II $\mathrm{SAB} / \mathrm{Ld} 163 / 15$

35 B. Adamiak, J. Borkowski, op. cit., s. 481.

36 Ustawa $z$ dnia 30 sierpnia 2002 r. - prawo o postępowaniu przed sądami administracyjnymi

(Dz. U. z 2018 r. poz. 1302, 1467, 1629, z 2019 r. poz. 11, 60.)

37 Wyrok Naczelnego Sądu Administracyjnego z dnia 10 kwietnia 2001 r. sygn. I SAB 37/00. 
swej pracy. Można więc przyjąć, iż z pewnością przyspieszy to pracę organów administracji publicznej.

Na drugie pytanie badawcze, również należy odpowiedzieć w sposób twierdzący, bowiem ustanowienie definicji legalnych w ustawie jest następstwem częstego określania tych terminów $\mathrm{w}$ orzecznictwie. Zatem ustawodawca postąpił prawidłowo. Samo wprowadzenie definicji legalnych owych terminów stwarza dużo mniejsze możliwości subiektywnej oceny wykładni przepisów prawa, stwarzającą jednocześnie bardziej korzystną sytuację dla organu administracji publicznej. Przepisy k.p.a. jasno precyzują terminy w których sprawa administracyjna powinna być załatwiona.

Należy zaznaczyć, że instytucja ponaglenia pozytywnie wpływa na szybkość postępowania administracyjnego. Grożące sankcje za opóźnienia przynoszą pozytywny efekt. De lege ferenda prowadzić to może do ustanowienia przez ustawodawcę jeszcze szerszego katalogu sankcji jakie będą grozić organowi i funkcjonariuszom publicznym za niezałatwienie sprawy w ustawowym terminie. Zaproponować de lege ferenda można również skrócenie terminu na przekazanie ponaglenia wraz z niezbędnymi aktami sprawy organowi II instancji poprzez wprowadzenie terminu - niezwłocznie, nie później niż w terminie 3 dni od dnia otrzymania ponaglenia.

\section{BIBLIOGRAFIA}

Adamiak B., Borkowski J., Postępowanie administracyjne i sądowoadministracyjne, Warszawa 2018. Adamiak B., Borkowski J., Postępowanie administracyjne i sq̨dowoadministracyjne, Warszawa 2013. Celińska-Grzegorczyk K., Hauser R., Sawczyn W., Skoczylas A., Postępowanie administracyjne, sadowoadministracyjne i egzekucyjne, Warszawa 2009

Chorąży K., Taras W., Wróbel A., Postępowanie administracyjne, egzekucyjne i sądowoadministracyjne, Zakamycze 2005

Dawidowicz W., Postępowanie administracyjne Zarys wyktadu, Warszawa 1983.

Kmieciak Z., Postępowanie administracyjne w świetle standardów europejskich, Warszawa 1997.

Kmiecik Z. R., Postępowanie administracyjne, postępowanie egzekucyjne w administracji i postępowanie sądowoadministracyjne, Warszawa 2017.

Konstytucja Rzeczypospolitej Polskiej z dnia 2 kwietnia 1997 r. (Dz.U. nr 78, poz. 483 ze zm.).

Ochendowski E., Postępowanie administracyjne ogólne, egzekucyjne i sądowoadministracyjne, Toruń 2008.

Szubiakowski M., Wierzbowski M., Wiktorowska A., Postępowanie administracyjne - ogólne, podatkowe i egzekucyjne, Warszawa 1996.

Ustawa z dnia 14 czerwca 1960 r. - Kodeks Postępowania administracyjnego (Dz. U. 1960 Nr 30 poz. 168).

Ustawa z dnia 30 sierpnia 2002r. - prawo o postępowaniu przed sądami administracyjnymi (Dz. U. z 2018 r. poz. 1302, 1467, 1629, z 2019 r. poz. 11, 60.)

Ustawa z dnia 20 stycznia 2011 r. o odpowiedzialności majątkowej funkcjonariuszy publicznych za rażące naruszenie prawa (Dz. U. z 2016r. poz. 1169 ze zm.). 
Ustawa z dnia 7 kwietnia 2017 r. o zmianie ustawy - Kodeks postępowania administracyjnego oraz niektórych innych ustaw (Dz.U. z 2017 r. poz. 935

Postanowienie WSA w Poznaniu z dnia 7 grudnia 2017 r., sygn. IV SAB/Po 70/17

Wyrok NSA z dnia 21 czerwca 1996 r., sygn. I SAB 28/96.

Wyrok NSA z dnia 10 kwietnia 2001 r. sygn. I SAB 37/00.

Wyrok NSA z dnia 10 lutego 2015 r., sygn. II OSK 2104/14.

Wyrok WSA w Gliwicach z dnia 25 września 2014 r., sygn. IV SAB/G1 92/14.

Wyrok WSA w Łodzi z dnia 8 grudnia 2015 r., sygn. II SAB/Ld 163/15.

Wyrok WSA w Gdańsku z dnia 18 stycznia 2017 r., sygn. II SAB/Gd 149/16.

\section{SUMMARY}

The purpose of this article is to present a new mean of challenge, i.e. a request for expediting, introduced to the Administrative Procedure Code. Earlier, when the authority did not settle the case within the time limit, the party could lodge a complaint. The complaint should be opposed by a request for expediting. The first part of the paper presents selected rules and terms binding in the Administrative Procedure Code. The following sections concern, among others, the definition of legal failure to act on the part of a public entity and excessive length of administrative proceedings. They present who can file a request for expediting. What are the ways of its examination? We will also find out what are the consequences of public entity being dilatory. The possibility of filing a request for expediting by a party or participant in the proceedings disciplines and mobilizes public administrative bodies for action.

Keywords: request for expediting; mean of challenge; public entity acting in a dilatory manner; failure to act on the part of a public entity; excessive length 